\title{
Effect of Drying Methods and Ultrasonication in Improving the Antioxidant Activity and Total Phenolic Content of Apple Pomace Powder
}

\author{
Umesh C. Lohani ${ }^{1} \&$ Kasiviswanathan Muthukumarappan ${ }^{1}$ \\ ${ }^{1}$ South Dakota State University, Brookings, SD 57006, USA \\ Correspondence: Umesh C. Lohani, Agricultural and Biosystems Engineering Department, South Dakota State \\ University, Brookings, SD, 57007-1496, USA. Tel: 1-605-690-6760. E-mail: umesh.lohani@sdstate.edu
}

Received: November 6, 2014 Accepted: December 23, $2014 \quad$ Online Published: December 30, 2014

doi:10.5539/jfr.v4n2p68

URL: http://dx.doi.org/10.5539/jfr.v4n2p68

\begin{abstract}
Although extrusion is a promising process to develop ready to eat cereals and snacks, thermal treatment to raw material during extrusion results in degradation of phenolic compounds. Therefore, an approach was made to enhance the total phenolic content (TPC) and antioxidant activity (AA) of apple pomace (AP) prior to extrusion process. In this study, AP powder was naturally fermented (F) for $12 \mathrm{~h}$ and then was subjected to ultrasonication (U) at various conditions [25, 37, and $50 \mu \mathrm{m}$ ultrasonication amplitude (UA) for 1, 2, and 3 min of ultrasonication time (UT)]. AP was then dried in oven (O) and microwave (MW), separately and thus four drying methods, i.e. $\mathrm{O}_{\mathrm{F}}-\mathrm{O}_{\mathrm{U}}, \mathrm{O}_{\mathrm{F}}-\mathrm{MW}_{\mathrm{U}}, \mathrm{MW}_{\mathrm{F}}-\mathrm{O}_{\mathrm{U}}, \mathrm{MW}_{\mathrm{F}}-\mathrm{MW}_{\mathrm{U}}$ were used in combinations. Full factorial design was used for experimental plan and results were analyzed using statistical software. It was observed that drying method significantly affected the TPC and AA of AP powder followed by UA. UT did not have any significant effect on TPC, and AA. Maximum TPC, and AA observed for the AP powder dried in MW after fermentation and ultrasonication $\left(\mathrm{MW}_{\mathrm{F}}-\mathrm{MW}_{\mathrm{U}}\right)$ at $50 \mu \mathrm{m}$ UA for 3 min UT were $372.98 \mathrm{mg} \mathrm{GAE} / 100 \mathrm{~g} \mathrm{DW}$, and $729.67 \mu \mathrm{mol}$ $\mathrm{TE} / 100 \mathrm{~g} \mathrm{DW}$, respectively. $\mathrm{MW}_{\mathrm{F}}-\mathrm{MW}_{\mathrm{U}}$ drying exhibited a more prominent disrupted and porous structure of AP powder compared with that of $\mathrm{O}_{\mathrm{F}}-\mathrm{O}_{\mathrm{U}}$ drying.
\end{abstract}

Keywords: apple pomace, fermentation, ultrasonication, microwave drying, total phenolic content, antioxidant activity

\section{Introduction}

Apple pomace (AP) is a solid residue ( $25 \%-30 \%$ of total fruit) obtained after the extraction of apple juice. AP is mainly composed of dietary fibers, carbohydrates, small amount of proteins, fat, and ash (Sudha, Baskaran, \& Leelavathi, 2007). It also contains numerous phytochemicals in the form of simple sugars, pectin, and natural antioxidants (Bhushan, Kalia, Sharma, Singh, \& Ahuja, 2008). The amount of total phenolic compounds (TPC) varies greatly in between flesh and peel of apple. Peel contains higher quantity of phenolic compounds. The procyanidins, catechin, epicatechin, chlorogenic acid, phloridzin and quercetin conjugates are commonly found in apple peels. In the apple flesh, catechin, procyanidins, epicatechin and phloridzin are found in much lower concentrations. Some of the phenolic compounds in AP have been correlated with antioxidant activities (AA) using various methods [2,2-diphenyl-1-picrylhydrazyl (DPPH), hydroxyl and superoxide anion radical scavenging activity, ferric reducing antioxidant power (FRAP)] and thereby confirming the AP as a valuable source of antioxidants (Diñeiro, Valles, \& Picinelli, 2009).

As a common application, AP is used for direct disposal to soil in a landfill, and for pectin recovery usage (gelling agent, stabilizer and source of dietary fiber). These applications are not sufficient to utilize the several tons of AP produced every year; therefore, studies have got momentum to valorize the AP for other purposes also. AP as a rich source of antioxidant compounds could be used for increasing the stability of foods by preventing lipid peroxidation and also for protecting oxidative damage in living systems by scavenging oxygen radicals. Extruded snacks, where starch is the major component, will have more nutritional value if incorporated with fiber enriched flours containing antioxidants. But, on the other hand, high temperature extrusion process also results in loss of nutritive values. From preliminary experiments, it was observed that extrusion at optimum temperature reduced $25-30 \% \mathrm{TPC}$ and $\mathrm{AA}$ of AP. Therefore, prior to extrusion, an effort is required to enhance 
the nutritive values, specially, TPC, and AA in AP. In past few years, ultrasonication and fermentation have been used for accelerating the extraction of phenolic antioxidants from AP (Ajila, Brar, Verma, Tyagi, \& Valéro, 2011; Ajila et al., 2012; Opalić et al., 2009; Vasantha Rupasinghe, Kathirvel, \& Huber, 2011; Virot, Tomao, Le Bourvellec, Renard, \& Chemat, 2010). Fermentation also brings about numerous biochemicals, nutritional and organoleptic changes in the raw materials including the breakdown of certain constituents (Murekatete, Hua, Kong, \& Zhang, 2012; Oboh \& Amusan, 2009). Several methods such as heat treatment, aqueous extraction, microwave assisted extraction and far-infrared radiation have been studied to liberate and activate natural antioxidants (Candrawinata, Golding, Roach, \& Stathopoulos, 2014; Grigoras, Destandau, Fougère, \& Elfakir, 2013; Kim et al., 2008; Reis, Rai, \& Abu-Ghannam, 2012). However, our comprehensive literature review revealed there has been very few detailed report on the use of microwaves and microwave drying to liberate phenolic compounds in plant materials and particularly none in case of AP. Therefore, keeping in view the above facts, the study was focused on enhancing the TPC and AA in AP powder using fermentation, ultrasonication and microwave (MW) drying technology.

\section{Materials and Methods}

Apple pomace (AP) powder provided by Tree Top, Inc. (Selah, WA) was stored at $-20{ }^{\circ} \mathrm{C}$. The initial moisture content of AP powder was $8.75 \%(w b)$. Protein, fat, ash, crude fiber and carbohydrate of AP powder were $4.14 \%$, $2.79 \%, 2.11 \%, 22.06 \%$, and $60.21 \%$, respectively. For natural fermentation, AP slurry was prepared by adding $12.5 \mathrm{~g}$ AP powder in $100 \mathrm{ml}$ distilled water. The fermentation was carried out in a controlled conditions with temperature $30 \pm 1{ }^{\circ} \mathrm{C}$ for $12 \mathrm{~h}$. Fermented slurry was dried and further subjected to ultrasoniaction at $25 \mu \mathrm{m}, 37$ $\mu \mathrm{m}$, and $50 \mu \mathrm{m}$ amplitude for 1,2 , and 3 min. Sample to water ratio was kept constant as $5 \%(\mathrm{w} / \mathrm{v})$ as a maximum concentration for ultrasonication from preliminary trials. Ultrasonicated sample was again dried and was stored at $-20{ }^{\circ} \mathrm{C}$ for TPC and AA analysis. Two methods, i.e. hot air oven $\left(50{ }^{\circ} \mathrm{C}\right)$ and microwave (MW) drying $(90 \mathrm{~W})$ were used for drying of sample till its constant weight. Four drying methods, i.e. $\mathrm{O}_{\mathrm{F}}-\mathrm{O}_{\mathrm{U}}, \mathrm{O}_{\mathrm{F}}-\mathrm{MW}_{\mathrm{U}}$ $\mathrm{MW}_{\mathrm{F}}-\mathrm{O}_{\mathrm{U}}, \mathrm{MW}_{\mathrm{F}}-\mathrm{MW}_{\mathrm{U}}$ were used in combinations (Table 1). Hot air oven drying was denoted by ' $\mathrm{O}$ ', and subscripts ' $F$ ', and ' $U$ ' indicated 'after fermentation', and 'after ultrasonication', respectively. For example, $\mathrm{MW}_{\mathrm{F}}-\mathrm{O}_{\mathrm{U}}$ indicates microwave drying after fermentation and hot air drying after ultrasonication.

Table 1. Independent variable values of the process and their corresponding levels

\begin{tabular}{llll}
\hline S. No & Independent variable & Level & Values \\
\hline 1 & Drying method & 4 & $\mathrm{O}_{\mathrm{F}}-\mathrm{O}_{\mathrm{U}}, \mathrm{O}_{\mathrm{F}}-\mathrm{MW}_{\mathrm{U}}, \mathrm{MW}_{\mathrm{F}}-\mathrm{O}_{\mathrm{U}}, \mathrm{MW}_{\mathrm{F}}-\mathrm{MW}_{\mathrm{U}}$ \\
2 & Ultrasonication amplitude, $\mu \mathrm{m}$ & 3 & $25,37,50$ \\
3 & Ultrasonication time, min & 3 & $1,2,3$ \\
\hline
\end{tabular}

O: Oven drying, MW: Microwave drying, F: Fermentation, U: Ultrasonication.

One gram of AP powder was weighed and extracted with $10 \mathrm{ml}$ of methanol. The methanol extract was centrifuged for $20 \mathrm{~min}$ at $2500 \times \mathrm{g}$. The fresh supernatant solution was collected and used for the determination of total phenolic content and antioxidant activity. All measurements were taken with six replications.

\subsection{Total Phenolic Content (TPC)}

TPC of AP powder was determined using method (Singleton, Orthofer, \& Lamuela-Raventós, 1999) with some modification. $50 \mu \mathrm{l}$ methanol extract of sample was added with $3.5 \mathrm{ml}$ distilled water and $150 \mu \mathrm{l}$ Folin Ciocalteu reagent. The solution was vortexed and incubated for $30 \mathrm{~min}$. Thereafter, absorbance of solution was measured at $760 \mathrm{~nm}$ against blank. Blank solution contained all the components that were present in the sample except the methanol extract. Gallic acid was used as positive control (standard) and linear regression curve between absorbance and concentration was drawn for the standard. This standard curve was used for calculating the concentration of sample and data was expressed in $\mathrm{mg}$ Gallic acid equivalent (GAE)/100 g dry weight (DW). This analysis was done in six replications.

\subsection{Antioxidant Activity (AA)}

Extinction of DPPH is a free radical scavenging activity which was measured using slightly modified spectrophotometric method described by (Brand-Williams, Cuvelier, \& Berset, 1995). 2,2-diphenyl-1-picrylhydrazyl (DPPH) solution was prepared by adding $7.9 \mathrm{mg}$ of DPPH in $200 \mathrm{ml}$ ethanol. 125 $\mu 1$ methanol extract was mixed with $2 \mathrm{ml}$ ethanol and $0.5 \mathrm{ml}$ of this solution was added with $3 \mathrm{ml} \mathrm{DPPH}$. The 
solution was vortexed and incubated for $30 \mathrm{~min}$. Thereafter, absorbance of solution and control (DPPH) was measured at $517 \mathrm{~nm}$ against blank (ethanol). Results were expressed as $\mu$ mol trolox equivalent (TE)/100 g dry weight (DW). Samples were analyzed in six replications.

\subsection{Moisture Content (MC)}

MC of AP powder was determined by air oven standard methods recommended by AOAC (1980). Initially $5 \mathrm{~g}$ of sample in triplicate was dried in hot air oven at $130-133{ }^{\circ} \mathrm{C}$ for $2 \mathrm{~h}$. After drying, dried sample was again weighed. Following formula is used for calculating the MC.

$$
\mathrm{MC}(\mathrm{wb}, \%)=\frac{w_{i}-W_{f}}{W_{i}} \times 100
$$

$\mathrm{W}_{\mathrm{i}}=$ initial weight of sample $(5 \mathrm{~g})$,

$\mathrm{W}_{\mathrm{f}}=$ weight of sample after drying, $\mathrm{g}$

\subsection{Microstructure Evaluation}

The microstructure of control, oven dried and MW dried Apple pomace powder was examined using a scanning electron microscope (SEM) (Hitachi-S3400 N, Tokyo, Japan). Small amounts of samples were mounted on SEM specimen stubs by using double-sided adhesive tape. Each powder sample was coated with $10 \AA$ thick layer of gold in a sputter coater before being scanned and photographed at $1000 \times$ magnification.

\subsection{Statistical Analysis}

Full factorial design was used for experimental plan and results were compared by analysis of variance (ANOVA) using SPSS (16.0) statistical software. All data were reported as mean \pm standard deviation of replicates. Tukey's tests were used to compare the significant differences of the mean values with the family error rate held at 0.05 . Pearson correlation test was employed to correlate total phenolic content and antioxidant activity.

\section{Results and Discussion}

\subsection{Effect of Drying Method on TPC and AA}

It was depicted by ANOVA that drying methods $(\mathrm{DM})$ had significant $(\mathrm{P}<0.05)$ effect on TPC and AA followed by interaction effect of drying method and UA (Table 2). Table 3 shows that TPC, and AA increased significantly by $20.1 \%$, and $47.9 \%$ on average when AP powder was MW dried after fermentation and ultrasonication as compare to oven drying during both the processes. Some other studies have also reported that the phenolic content was increased after microwave treatment of the plant materials (Boateng, Verghese, Walker, \& Ogutu, 2008; Hayat et al., 2010; Omwamba \& Hu, 2010). However, Sharma and Gujral (2011) found decrease in TPC of barley after microwave cooking. Microwave treatment of AP powder cleaved and liberated phenolic compounds, hence resulting in the increase of free phenolic compounds and enhancement of antioxidant activity. $\mathrm{O}_{\mathrm{F}}-\mathrm{MW}_{\mathrm{U}}$, and $\mathrm{MW}_{\mathrm{F}}-\mathrm{O}_{\mathrm{U}}$ drying methods did not show any significant difference in TPC, while there was no significant difference in $\mathrm{AA}$ between $\mathrm{MW}_{\mathrm{F}}-\mathrm{O}_{\mathrm{U}}$ and $\mathrm{MW}_{\mathrm{F}}-\mathrm{MW}_{\mathrm{U}}$ drying methods. TPC of AP powder was found least during $\mathrm{O}_{\mathrm{F}}-\mathrm{O}_{\mathrm{U}}$ drying that may be because of thermal degradation of TPC. When AP powder was MW dried after fermentation, and ultrasonication at $50 \mu \mathrm{m}$ UA for 3 min UT, TPC and AA were increased by $27 \%$, and $66.3 \%$, respectively, as compare to oven dried during both the processes (Figure 1). Maximum TPC, and AA observed for the AP powder for $\mathrm{MW}_{\mathrm{F}}-\mathrm{MW}_{\mathrm{U}}$ at $50 \mu \mathrm{m}$ UA for 3 min UT were $16.7 \%$, and $88.5 \%$ more than that of control (untreated AP powder), respectively. TPC value obtained from $\mathrm{MW}_{\mathrm{F}}-\mathrm{O}_{\mathrm{U}}$ drying method was not significantly $(p>0.05)$ different than that of control AP powder. $\mathrm{O}_{\mathrm{F}}-\mathrm{O}_{\mathrm{U}}$ and $\mathrm{O}_{\mathrm{F}}-\mathrm{MW}_{\mathrm{U}}$ drying method did not show any significant difference in AA values with compare to that of control AP powder (Figure 1). Apart from enhancing the TPC and AA of AP powder, $\mathrm{MW}_{\mathrm{F}}-\mathrm{MW}_{\mathrm{U}}$ drying saved $65 \%$ of drying time as compared to $\mathrm{O}_{\mathrm{F}}-\mathrm{O}_{\mathrm{U}}$ drying (data not shown). 
Table 2. Variance analysis for all dependent variables

\begin{tabular}{|c|c|c|c|c|c|c|}
\hline Source & $\begin{array}{l}\text { Dependent } \\
\text { variables }\end{array}$ & $\begin{array}{l}\text { Type III sum of } \\
\text { square }\end{array}$ & $\mathrm{df}$ & $\begin{array}{l}\text { Mean } \\
\text { square }\end{array}$ & F value & $P$ value \\
\hline \multirow{2}{*}{$\begin{array}{l}\text { Drying } \\
\text { (DM) }\end{array}$} & TPC & 47302.72 & 3 & 157.6757 & 110.67 & $0.000^{*}$ \\
\hline & $\mathrm{AA}$ & 678833.34 & 3 & 226277.78 & 58.83 & $0.000 *$ \\
\hline \multirow{2}{*}{$\begin{array}{l}\text { Ultrasonication } \\
\text { amplitude (UA) }\end{array}$} & TPC & 8732.72 & 2 & 4366.36 & 30.65 & $0.000^{*}$ \\
\hline & $\mathrm{AA}$ & 187686.93 & 2 & 93843.47 & 24.4 & $0.000 *$ \\
\hline \multirow{2}{*}{$\begin{array}{l}\text { Ultrasonication time } \\
\text { (UT) }\end{array}$} & TPC & 64.37 & 2 & 32.18 & 0.23 & 0.798 \\
\hline & $\mathrm{AA}$ & 1460.91 & 2 & 730.45 & 0.19 & 0.827 \\
\hline \multirow[t]{2}{*}{$\mathrm{DM}^{*} \mathrm{UA}$} & ТPC & 3958.22 & 6 & 659.70 & 4.63 & $0.000^{*}$ \\
\hline & $\mathrm{AA}$ & 159417.69 & 6 & 26569.62 & 6.91 & $0.000^{*}$ \\
\hline \multirow[t]{2}{*}{$\mathrm{DM} * \mathrm{UT}$} & ТPC & 238.89 & 6 & 39.82 & 0.28 & 0.945 \\
\hline & $\mathrm{AA}$ & 33112.20 & 6 & 5518.70 & 1.43 & 0.213 \\
\hline \multirow[t]{2}{*}{$\mathrm{UA} * \mathrm{UT}$} & ТPC & 382.54 & 4 & 95.64 & 0.67 & 0.614 \\
\hline & $\mathrm{AA}$ & 23506.46 & 4 & 5876.61 & 1.53 & 0.203 \\
\hline \multirow[t]{2}{*}{$\mathrm{DM} * \mathrm{UA} * \mathrm{UT}$} & TPC & 584.38 & 12 & 48.69 & 0.34 & 0.978 \\
\hline & $\mathrm{AA}$ & 53277.46 & 12 & 4439.79 & 1.15 & 0.332 \\
\hline
\end{tabular}

*significant at $5 \%$ level of significance.

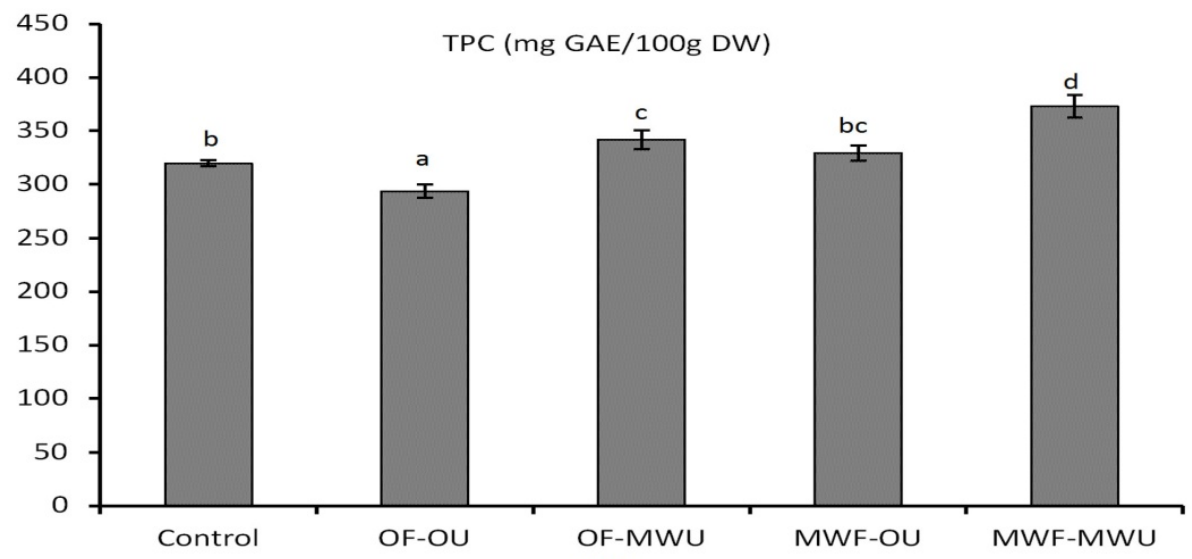

(A)

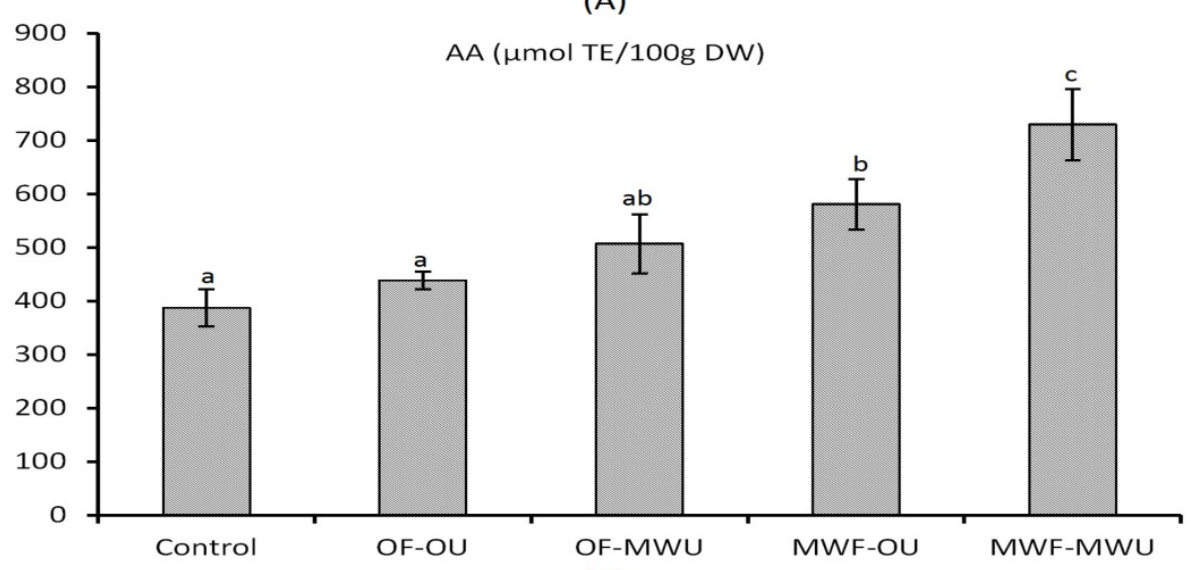

(B)

Figure 1. Effect of drying methods on TPC (A) and AA (B) of apple pomace powder at $50 \mu \mathrm{m}$ UA for 3 min UT (O: oven drying, MW: microwave drying, F: fermentation, U: ultrasonication). Bars with different letters are significantly $(\mathrm{P}<0.05)$ different 


\subsection{Effect of UA and UT on TPC and AA}

It was explicated by ANOVA that there was significant $(\mathrm{P}<0.05)$ effect of $\mathrm{UA}$, and interaction of UA and drying method on TPC and AA of AP powder (Table 2). TPC and AA of AP powder increased significantly with increase in UA from $25 \mu \mathrm{m}$ to $50 \mu \mathrm{m}$ (Table 3). The reason may be that an increase in UA resulted in disruption of cell compartments facilitating the interaction of phenolic molecules with solvents at reasonably low temperatures. Alighourchi, Barzegar, Sahari, and Abbasi (2013) also observed an increase in TPC of pomegranate juice with increase in ultrasound power. For all drying methods and $3 \mathrm{~min}$ of UT, TPC increased nonlinearly with increase in UA from $25 \mu \mathrm{m}$ to $50 \mu \mathrm{m}$, however, only during $\mathrm{O}_{\mathrm{F}}-\mathrm{MW}_{\mathrm{U}}$ and $\mathrm{MW}_{\mathrm{F}}-\mathrm{MW}_{\mathrm{U}}$ drying, TPC increased significantly $(\mathrm{p}<0.05)$ with increase in UA from $25 \mu \mathrm{m}$ to $37 \mu \mathrm{m}$ and $37 \mu \mathrm{m}$ to $50 \mu \mathrm{m}$, respectively (Figure 2). Except $\mathrm{O}_{\mathrm{F}}-\mathrm{O}_{\mathrm{U}}$ drying, all drying methods showed the significant $(\mathrm{p}<0.05)$ difference in TPC values between $25 \mu \mathrm{m}$ and $50 \mu \mathrm{m}$ UA (Figure 2). With increase in UA, AA also increased for all drying methods except $\mathrm{O}_{\mathrm{F}}-\mathrm{MW}_{\mathrm{U}}$ method. For this drying method, AA first decrease with increase in UA from $25 \mu \mathrm{m}$ to $37 \mu \mathrm{m}$ and thereafter increased with UA up to $50 \mu \mathrm{m}$ (Figure 2). $\mathrm{O}_{\mathrm{F}}-\mathrm{O}_{\mathrm{U}}$ and $\mathrm{O}_{\mathrm{F}}-\mathrm{MW}_{\mathrm{U}}$ drying method did not exhibit any significant $(\mathrm{p}>0.05)$ change in AA of AP powder when UA increased from $25 \mu \mathrm{m}$ to $50 \mu \mathrm{m}$ for 3 min UT (Figure 2). A significant $(\mathrm{p}<0.05)$ difference in AA of AP powder was observed between $25 \mu \mathrm{m}$ and 50 $\mu \mathrm{m}$ UA during $\mathrm{MW}_{\mathrm{F}}-\mathrm{O}_{\mathrm{U}}$ drying, whereas, $\mathrm{MW}_{\mathrm{F}}-\mathrm{MW}_{\mathrm{U}}$ drying showed a continuous significant $(\mathrm{p}<0.05)$ increase in AA with increase in UA in experimental range (Figure 2). When MW dried fermented and ultrasonicated AP powder was subjected to an increase in UA from $25 \mu \mathrm{m}$ to $50 \mu \mathrm{m}$ for 3 min UT, TPC, and AA were increased by $10.7 \%$, and $80.4 \%$, respectively. Maximum TPC and AA were found as $372.98 \mathrm{mg} \mathrm{GAE} / 100 \mathrm{~g} \mathrm{DW}$ and 729.67 $\mu \mathrm{mol} \mathrm{TE} / 100 \mathrm{~g}$ DW, respectively at $50 \mu \mathrm{m} \mathrm{UA}$ and $\mathrm{MW}_{\mathrm{F}}-\mathrm{MW}_{\mathrm{U}}$ drying method (Table 3).

Table 2 and Figure 3 shows that there was no significant $(\mathrm{p}>0.05$ ) change in TPC, and AA with increase in UT from 1 to 3 min, although maximum TPC and AA were found for 3 min of UT at $50 \mu \mathrm{m}$ UA and $M_{\mathrm{F}}-\mathrm{MW}_{\mathrm{U}}$ drying (Table 3). The reason of this may be due to short time exposure of AP powder to the ultrasonication.

Table 3. Main effect of independent variables on responses

\begin{tabular}{llll}
\hline Independent variables & Values & TPC $(\mathrm{mg} \mathrm{GAE} / 100 \mathrm{~g} \mathrm{DW})$ & $\mathrm{AA}(\mu \mathrm{mol} \mathrm{TE} / 100 \mathrm{~g} D W)$ \\
\hline Drying method & $\mathrm{O}_{\mathrm{F}}-\mathrm{O}_{\mathrm{U}}$ & $291.62 \pm 10.29^{\mathrm{a}}$ & $417.95 \pm 25.26^{\mathrm{a}}$ \\
& $\mathrm{O}_{\mathrm{F}}-\mathrm{MW}_{\mathrm{U}}$ & $326.96 \pm 12.54^{\mathrm{b}}$ & $478.45 \pm 49.19^{\mathrm{b}}$ \\
& $\mathrm{MW}_{\mathrm{F}-\mathrm{O}_{\mathrm{U}}}$ & $318.92 \pm 10.43^{\mathrm{b}}$ & $578.25 \pm 54.69^{\mathrm{c}}$ \\
& $\mathrm{MW}_{\mathrm{F}}-\mathrm{MW}_{\mathrm{U}}$ & $350.20 \pm 11.53^{\mathrm{c}}$ & $618.23 \pm 49.11^{\mathrm{c}}$ \\
$\mathrm{UA}, \mu \mathrm{m}$ & 25 & $310.86 \pm 11.45^{\mathrm{a}}$ & $469.54 \pm 22.87^{\mathrm{a}}$ \\
& 37 & $332.88 \pm 9.97^{\mathrm{b}}$ & $571.18 \pm 26.85^{\mathrm{b}}$ \\
\multirow{2}{*}{ UT, min } & 50 & $322.03 \pm 10.36^{\mathrm{c}}$ & $528.94 \pm 33.94^{\mathrm{c}}$ \\
& 1 & $323.01 \pm 10.06^{\mathrm{a}}$ & $527.37 \pm 19.66^{\mathrm{a}}$ \\
& 2 & $321.31 \pm 9.45^{\mathrm{a}}$ & $523.85 \pm 13.58^{\mathrm{a}}$ \\
& 3 & $321.45 \pm 10.66^{\mathrm{a}}$ & $518.43 \pm 13.69^{\mathrm{a}}$
\end{tabular}

Values within columns for individual variables with different superscript letters are significantly $(\mathrm{p}<0.05)$ different. O: Oven drying, MW: Microwave drying, F: Fermentation, U: Ultrasonication. 


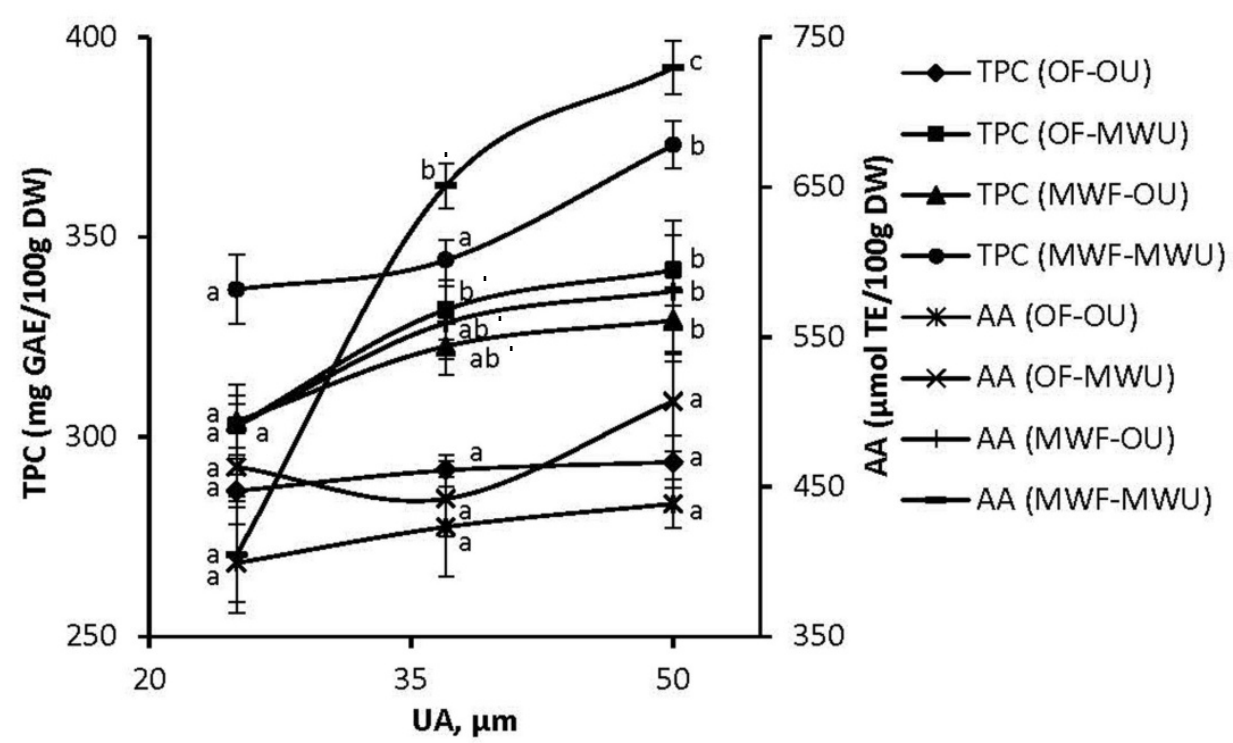

Figure 2. Effect of UA on TPC and AA of apple pomace powder for 3 min UT for all drying methods. Mean values in the same line with different letters are significantly $(\mathrm{p}<0.05)$ different

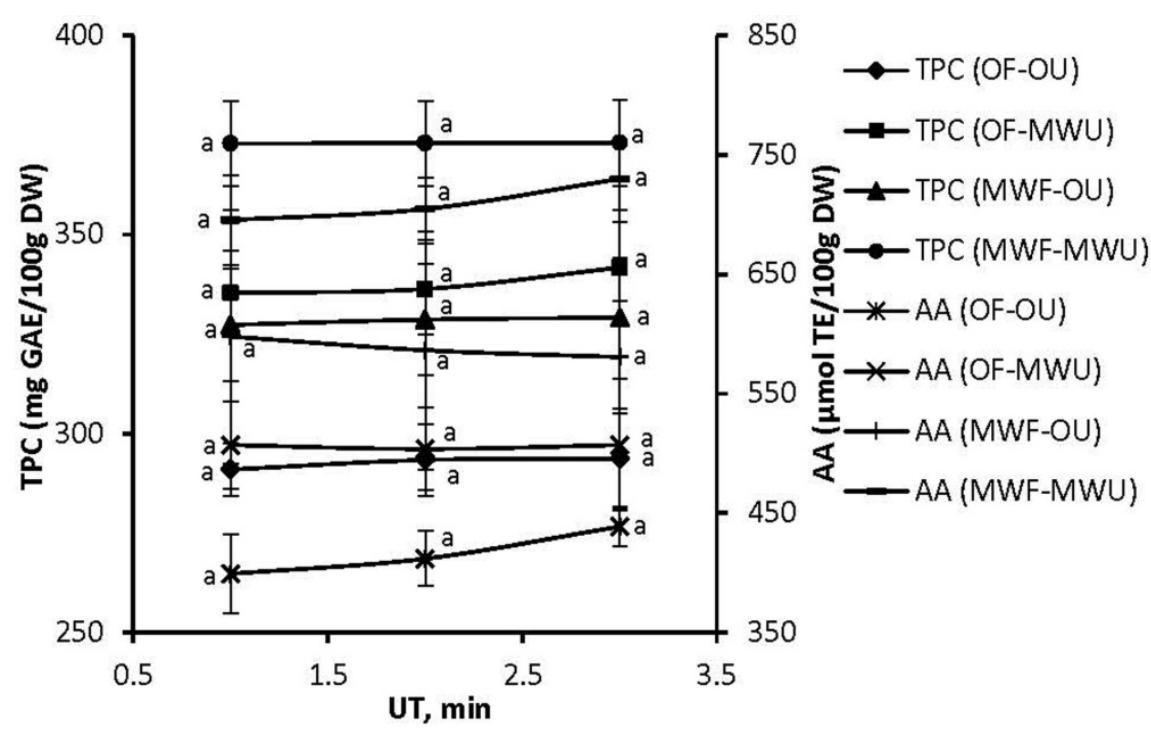

Figure 3. Effect of UT on TPC and AA of AP powder at $50 \mu \mathrm{m}$ UA for all drying methods. Mean values in the same line with different letters are significantly $(\mathrm{p}<0.05)$ different

\subsection{Effect of Processing on Microstructures of AP Powder}

The effect of the drying conditions on the microstructure of treated (fermented and ultrasonicated at $50 \mu \mathrm{m}$ amplitude for $3 \mathrm{~min}$ ) AP powder was carried out by means of SEM. The microphotographs of fresh, $\mathrm{O}_{\mathrm{F}}-\mathrm{O}_{\mathrm{U}}$ and $\mathrm{MW}_{\mathrm{F}}-\mathrm{MW}_{\mathrm{U}}$ AP powder are shown in Figure 4. Figure 4a shows the structure of fresh AP powder, which is a compact and less porous structure. The SEM images revealed that hot air drying $\left(\mathrm{O}_{\mathrm{F}}-\mathrm{O}_{\mathrm{U}}\right)$ resulted in modification of the cellular structure (Figure 4b). MW drying after fermentation and ultrasonication $\left(\mathrm{MW}_{\mathrm{F}}-\mathrm{MW}_{\mathrm{U}}\right)$ damaged the plant cell structure and caused more porosity (Figure $\left.4 \mathrm{c}\right)$. Similar results were found by Giri and Prasad (2007) and Han, Yin, Li, Yang, and Ma (2010) for mushroom and apple slices, respectively. MW dried sample granules were more disrupted than hot air dried granules which caused increase in change into surface area and released more phenolics from bound structure. 


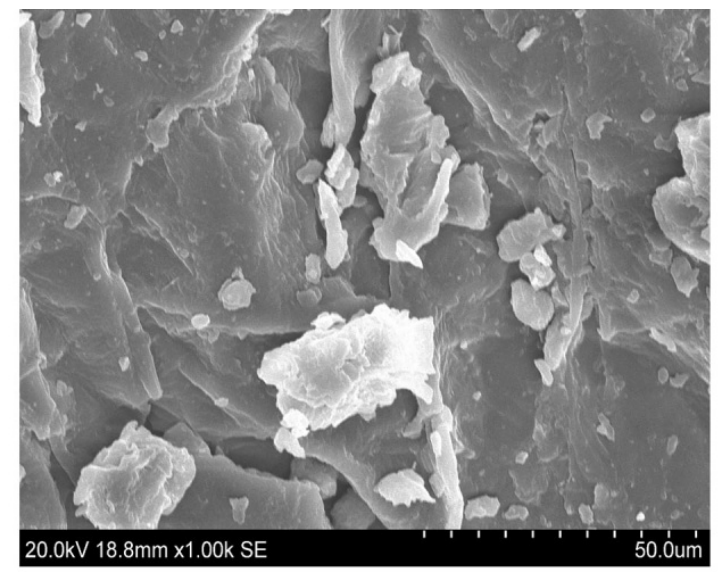

a

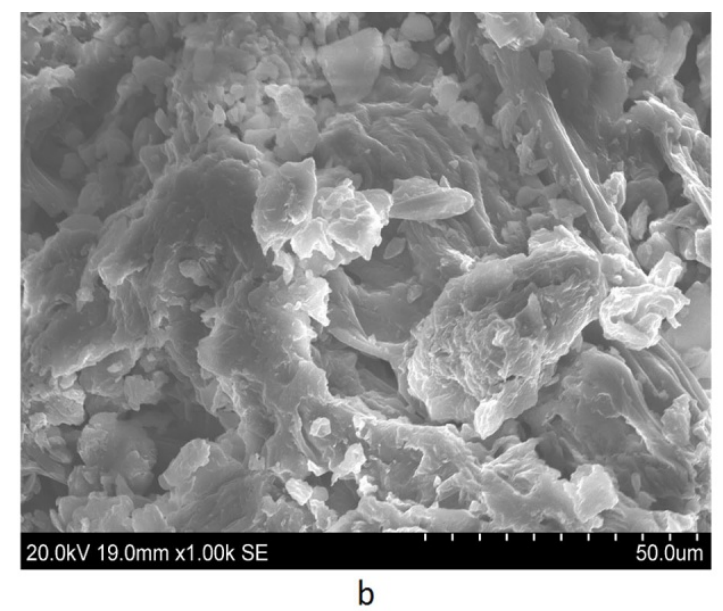

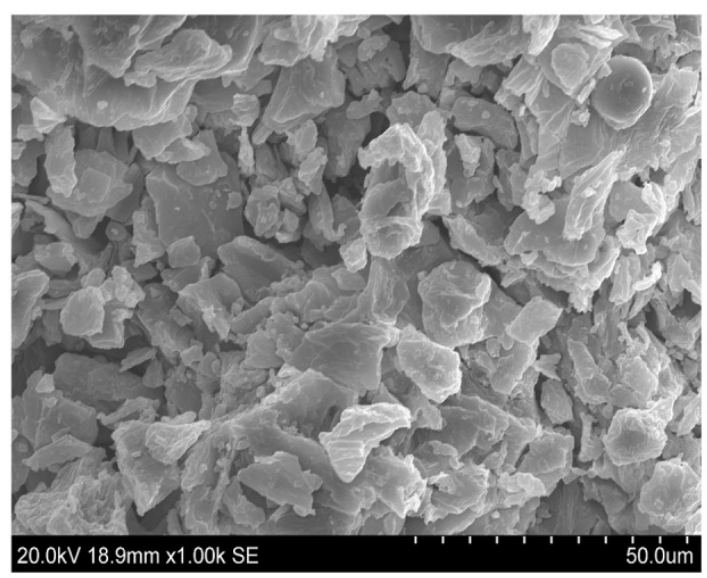

C

Figure 4. Scanning electron micrographs ( $\times 1000$ magnification $)$ of fresh (a), $\mathrm{O}_{\mathrm{F}}-\mathrm{O}_{\mathrm{U}}(\mathrm{b})$, and $\mathrm{MW}$ - $-\mathrm{MW}_{\mathrm{U}}(\mathrm{c}) \mathrm{AP}^{\mathrm{P}}$ powder (12 $\mathrm{h}$ fermentation, ultrasonication at $50 \mu \mathrm{m}$ amplitude for $3 \mathrm{~min}$ )

\subsection{Relationship Between TPC and AA}

The correlation coefficients between TPC and AA (DPPH assay), after fermentation and ultrasonic treatment of sorghum flour, are shown in Figure 5. Correlation experiments to predict the antioxidant properties have been performed by many authors. AP powder with higher levels of TPC had a greater antioxidant capacity (Sato et al., 2010; Savatović, Đilas, Tumbas, Čanadanović-Brunet, \& Ćetković, 2005). The values of AA indicated a positive correlation with the values of TPC of AP powder at different drying method, and ultrasonication amplitude (UA). A linear correlation in each case was observed between AA and TPC. The correlation coefficient (r) were 0.9474 , and 0.9960 at different drying method and UA, respectively, which indicated that TPC was the major factor accounting for the antioxidant activity of the sorghum flour. 


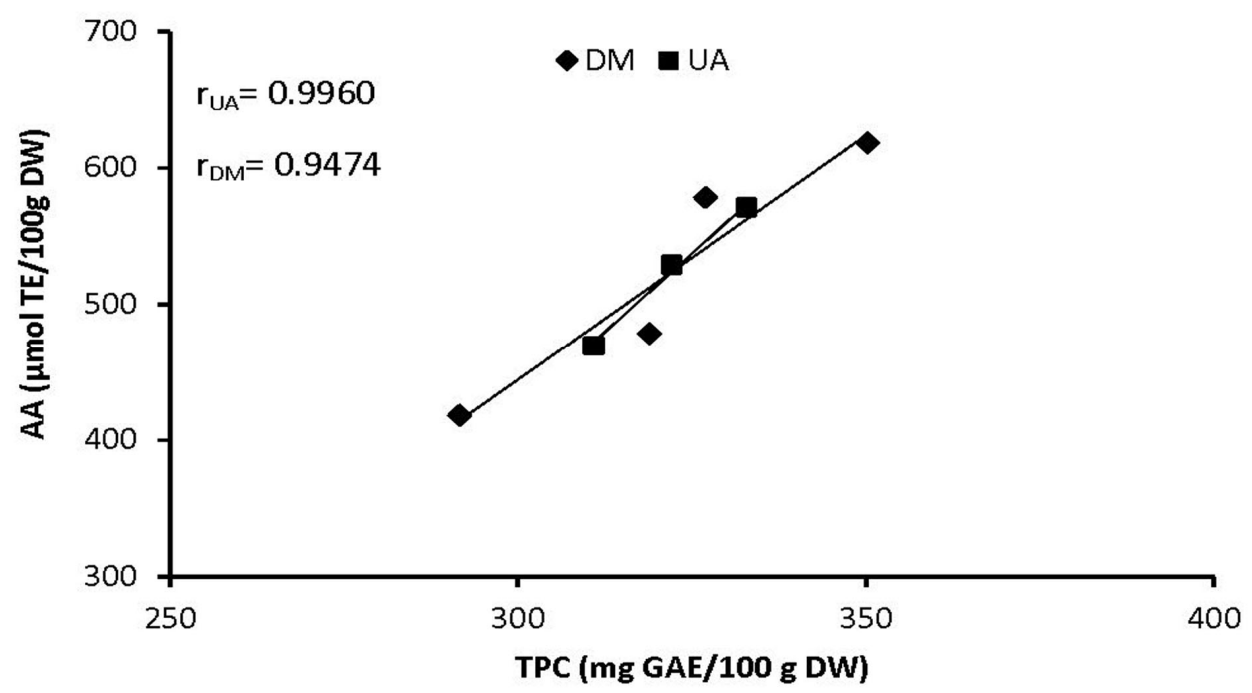

Figure 5. Correlation between TPC and AA of AP powder for different drying methods (DM) and ultrasonication amplitude (UA)

\section{Conclusions}

Drying method of AP after fermentation and ultrasonication played a significant role in enhancing the TPC, and AA in AP powder followed by UA. UT did not have any significant effect on TPC, and AA. Higher UA with MW drying during fermentation and ultrasonication process gave the higher values of TPC, and AA. From the microstructural analysis, MW drying caused more cell collapse and cell disruption resulting in release of phenolics from the bound structure. MW drying is also favorable for quick and efficient drying as compare to oven drying. AA of AP powder showed the linear correlation with TPC. More investigation is required to observe the effect of further increase in UA and UT on TPC and AA of AP powder.

\section{Acknowledgements}

The authors gratefully acknowledge the funding provided by Agricultural Experiment Station, College of Agriculture and Biological Sciences, South Dakota State University. We would also like to thank Tree Top Inc. (Selah, WA) for providing apple pomace powder used in this research.

\section{References}

Ajila, C. M., Brar, S. K., Verma, M., Tyagi, R. D., \& Valéro, J. R. (2011). Solid-state fermentation of apple pomace using Phanerocheate chrysosporium - Liberation and extraction of phenolic antioxidants. Food Chemistry, 126(3), 1071-1080. http://dx.doi.org/10.1016/j.foodchem.2010.11.129

Ajila, C. M., Gassara, F., Brar, S., Verma, M., Tyagi, R. D., \& Valéro, J. R. (2012). Polyphenolic Antioxidant Mobilization in Apple Pomace by Different Methods of Solid-State Fermentation and Evaluation of Its Antioxidant Activity. Food and Bioprocess Technology, 5(7), 2697-2707. http://dx.doi.org/10.1007/s11947-011-0582-y

Alighourchi, H. R., Barzegar, M., Sahari, M. A., \& Abbasi, S. (2013). Effect of sonication on anthocyanins, total phenolic content, and antioxidant capacity of pomegranate juices. International Food Research Journal, 20(4), 1703-1709.

AOAC. (1980). Official methods of analysis. Air oven method (13 ed.). Washington, DC: Association of Official Analytical Chemist, 211.

Bhushan, S., Kalia, K., Sharma, M., Singh, B., \& Ahuja, P. S. (2008). Processing of Apple Pomace for Bioactive $\begin{array}{llll}\text { Molecules. Critical Reviews in } & \text { 285-296. }\end{array}$ http://dx.doi.org/10.1080/0738855080236885

Boateng, J., Verghese, M., Walker, L. T., \& Ogutu, S. (2008). Effect of processing on antioxidant contents in selected dry beans (Phaseolus spp. L.). LWT - Food Science and Technology, 41(9), 1541-1547. http://dx.doi.org/10.1016/j.lwt.2007.11.025 
Brand-Williams, W., Cuvelier, M. E., \& Berset, C. (1995). Use of a free radical method to evaluate antioxidant

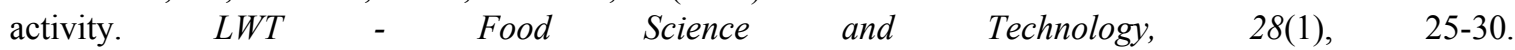
http://dx.doi.org/10.1016/s0023-6438(95)80008-5

Candrawinata, V. I., Golding, J. B., Roach, P. D., \& Stathopoulos, C. E. (2014). Optimisation of the phenolic content and antioxidant activity of apple pomace aqueous extracts. CyTA - Journal of Food, 1-7. http://dx.doi.org/10.1080/19476337.2014.971344

Diñeiro, G. Y., Valles, B. S., \& Picinelli, L. A. (2009). Phenolic and antioxidant composition of by-products from the cider industry: Apple pomace. Food Chemistry, 117(4), 731-738. doi: http://dx.doi.org/10.1016/j.foodchem.2009.04.049

Giri, S. K., \& Prasad, S. (2007). Drying kinetics and rehydration characteristics of microwave-vacuum and convective hot-air dried mushrooms. Journal of Food Engineering, 78(2), 512-521. http://dx.doi.org/10.1016/j.jfoodeng.2005.10.021

Grigoras, C. G., Destandau, E., Fougère, L., \& Elfakir, C. (2013). Evaluation of apple pomace extracts as a source of bioactive compounds. Industrial Crops and Products, 49(0), 794-804. http://dx.doi.org/10.1016/j.indcrop.2013.06.026

Han, Q.-H., Yin, L.-J., Li, S.-J., Yang, B.-N., \& Ma, J.-W. (2010). Optimization of Process Parameters for Microwave Vacuum Drying of Apple Slices Using Response Surface Method. Drying Technology, 28(4), 523-532. http://dx.doi.org/10.1080/07373931003618790

Hayat, K., Zhang, X., Farooq, U., Abbas, S., Xia, S., Jia, C., ... Zhang, J. (2010). Effect of microwave treatment on phenolic content and antioxidant activity of citrus mandarin pomace. Food Chemistry, 123(2), 423-429. http://dx.doi.org/10.1016/j.foodchem.2010.04.060

Kim, J.-W., Bae, H.-C., Kim, M.-C., \& Lee, S.-C. (2008). Effect of far-infrared irradiation on the antioxidant activity of puerariae radix extract. Journal of Food Biochemistry, 32(1), 85-95. http://dx.doi.org/10.1111/j.1745-4514.2007.00148.x

Murekatete, N., Hua, Y., Kong, X., \& Zhang, C. (2012). Effects of Fermentation on Nutritional and Functional Properties of Soybean, Maize, and Germinated Sorghum Composite Flour. International Journal of Food Engineering, 8(1), 1-15. http://dx.doi.org/10.1515/1556-3758.2646

Oboh, G., \& Amusan, T. V. (2009). Nutritive Value and Antioxidant Properties of Cereal Gruels Produced from Fermented Maize and Sorghum. Food Biotechnology, 23(1), 17-31. http://dx.doi.org/10.1080/08905430802671899

Omwamba, M., \& Hu, Q. (2010). Antioxidant Activity in Barley (Hordeum vulgare L.) Grains Roasted in a Microwave Oven under Conditions Optimized Using Response Surface Methodology. Journal of Food Science, 75(1), C66-C73. http://dx.doi.org/10.1111/j.1750-3841.2009.01426.x

Opalić, M., Domitran, Z., Komes, D., Belščak, A., Horžić, D., \& Karlović, D. (2009). The effect of ultrasound pre-treatment and air-drying on the quality of dried apples. Czech Journal of Food Science, 27(SI), S297-S300.

Reis, S. F., Rai, D. K., \& Abu-Ghannam, N. (2012). Water at room temperature as a solvent for the extraction of apple pomace phenolic compounds. Food Chemistry, 135(3), 1991-1998. http://dx.doi.org/10.1016/j.foodchem.2012.06.068

Sato, M. F., Vieira, R. G., Zardo, D. M., Falcão, L. D., Nogueira, A., \& Wosiacki, G. (2010). Apple pomace from eleven cultivars: an approach to identify sources of bioactive compounds. Acta Scientiarum. Agronomy. http://dx.doi.org/10.4025/actasciagron.v32i1.3176

Savatović, S. M., Đilas, S. M., Tumbas, V. T., Čanadanović-Brunet, J. M., \& Ćetković, G. S. (2005). Antioxidant activity of Induna apple pomace extract. Acta Periodica Technologica. http://dx.doi.org/10.2298/apt0536239s

Sharma, P., \& Gujral, H. S. (2011). Effect of sand roasting and microwave cooking on antioxidant activity of barley. Food Research International, 44(1), 235-240. http://dx.doi.org/10.1016/j.foodres.2010.10.030

Singleton, V. L., Orthofer, R., \& Lamuela-Raventós, R. M. (1999). Analysis of total phenols and other oxidation substrates and antioxidants by means of folin-ciocalteu reagent. Methods in Enzymology, 299, 152-178. http://dx.doi.org/10.1016/S0076-6879(99)99017-1 
Sudha, M. L., Baskaran, V., \& Leelavathi, K. (2007). Apple pomace as a source of dietary fiber and polyphenols and its effect on the rheological characteristics and cake making. Food Chemistry, 104(2), 686-692. http://dx.doi.org/10.1016/j.foodchem.2006.12.016

Vasantha Rupasinghe, H. P., Kathirvel, P., \& Huber, G. M. (2011). Ultrasonication-Assisted Solvent Extraction of Quercetin Glycosides from 'Idared' Apple Peels. Molecules, 16(12), 9783-9791. http://dx.doi.org/10.3390/molecules16129783

Virot, M., Tomao, V., Le Bourvellec, C., Renard, C. M. C. G., \& Chemat, F. (2010). Towards the industrial production of antioxidants from food processing by-products with ultrasound-assisted extraction. Ultrasonics Sonochemistry, 17(6), 1066-1074. http://dx.doi.org/10.1016/j.ultsonch.2009.10.015

\section{Copyrights}

Copyright for this article is retained by the author(s), with first publication rights granted to the journal.

This is an open-access article distributed under the terms and conditions of the Creative Commons Attribution license (http://creativecommons.org/licenses/by/3.0/). 